\title{
Why Did Borrowers Apply For Debt Restructuring During The COVID-19 Pandemic?
}

\author{
Hafidz Syihab ${ }^{1 *}$, Zuliani Dalimunthe ${ }^{2}$ \\ ${ }^{1}$ University of Indonesia, hafidz.syihab@gmail.com \\ ${ }^{2}$ University of Indonesia, zuliani_d@ui.ac.id \\ *Corresponding author
}

\begin{abstract}
The Coronavirus pandemic impacts Indonesia's economic activity and increases bank loan default risk. Therefore, the Financial Services Authority regulates the provisions for restructuring credit facilities for debtors directly or indirectly affected by the pandemic. This study is to analyze the profile of debtors in times of crisis, what kind of debtor profile might apply for credit restructuring. We analyze a set of debtor profiles from SMEs to ascertain which factors determine the probability of restructuring credit facilities during covid19. This research uses a debtor profile estimation method for Small and Medium Enterprises. To analyze the data we used logistic regression method and discriminant analysis method. We collect the data from one of the largest banks in Indonesia. We found that the debtor's business age, the loan limit provided by the Bank, loan size, and debtors' profitability were factors that can explain why debtors apply for debt restructuring during the pandemic. This study was conducted to provide empirical evidence that several factors can influence the quality of debtor credit facilities during the pandemic of COVID-19.
\end{abstract}

Keywords: COVID-19, Small Medium Enterprises, debt restructuring, logistic regression, discriminant analysis.

\section{INTRODUCTION}

The first case of Coronavirus (COVID-19) was reported in December 2019 in Wuhan, (Huang et al., 2020). The World Health Organization (WHO) categorizes this incident as a pandemic. With the development of the coronavirus disease in all over the world, the COVID-19 outbreak has become a global biological disaster, one of the most serious disasters in human history. The coronavirus disease has significant potential for the economic in China, United States, India, and other parts of the world (Chakraborty and Maity, 2020). Therefore, to prevent and control the pandemic outbreak, special attention is needed to collaborate between health workers, the government and the community in general (Yoo, 2020).

COVID-19 has worsened the global economy, many countries affected by this outbreak have decided to lockdown. With the lockdown on all domestic flights, trains (except freight trains), buses, trucks and other vehicles, restrictions are made with special exceptions related to commodities. In most countries hit by COVID-19, activities in the fields of education, commercial, sports and spiritual institutions have been temporarily suspended.

The productivity level has become very low, high inflation and rising unemployment due to decreased productivity and excessive spending for handling Coronavirus by the government are experienced by many countries. Lockdown will directly affect the economy and GDP of the country. It is estimated that every month there will be a $2 \%$ decline in annual gross domestic product growth and the tourism sector itself is expected to experience a drop of $50 \%$ to $70 \%$ (Chakraborty and Maity, 2020). The pandemic has also disrupted supply chains, as many employees feel that their health will be compromised if they go to work, and of course, this will impact certain sectors. On the other hand, other economic sectors such as information technology, were not significantly affected or had a positive impact (Kwan and Mertens 2020). Based on the Organization for Economic Cooperation and Development (OECD) and the World Trade Organization (WTO) indicate that the greatest threat to the global economy exceeds the financial crisis of 2008 2009 is the COVID-19 pandemic. 


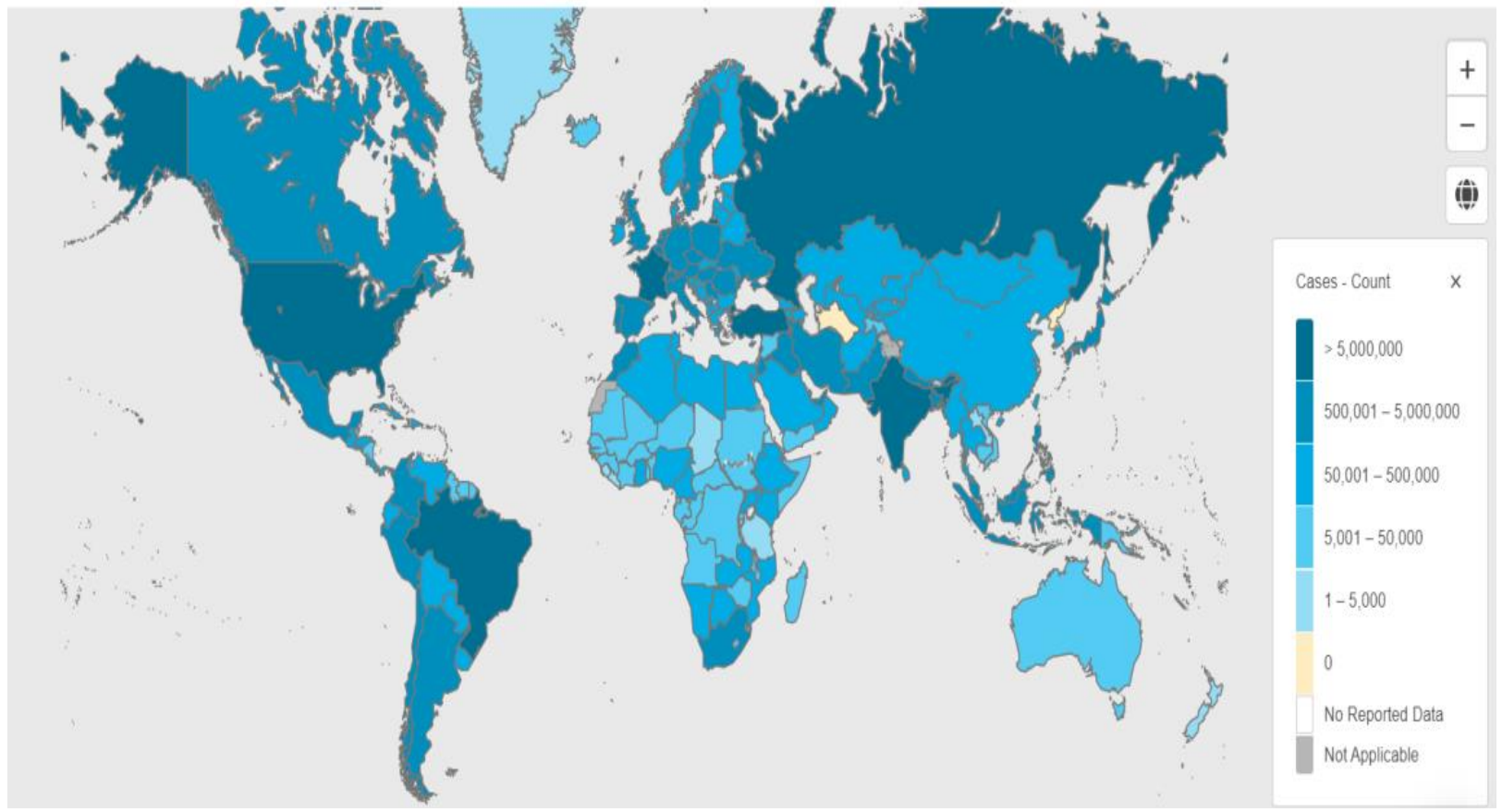

Data distribution of COVID-19

(Source: WHO, 2021, Accessed date: 11 Juni 2021).

The perceived impact is quite significant in Indonesia. Based on March 13, 2020, The Financial Services Authority released regulation No. 11/POJK.03/2020, regarding the national economic stimulus as a policy due to the impact of the spread of Coronavirus Disease, explains that the effect directly effect or indirectly affects the performance of micro, small and medium business debtors (SME's), which of course can disrupt the performance of the banking and financial system in terms of economic growth. The Law of the Ministry of Finance released regulation No. 2 of 2020 on March 31, 2020, regarding state financial policies and financial system stability for handling the Coronavirus pandemic, which states that there are implications from the coronavirus pandemic which have an impact on the slowdown in national economic growth, decreased state revenues and increased state spending, so that various efforts are needed to save health and the national economy with a focus on the economic recovery of businesses and communities affected by COVID-19, in other words, this is related to protecting the businesses of debtors who have influenced the impact of this pandemic.

There is a survey about the impact of COVID19 on business actors conducted by the Central Statistics Agency that there is a significant influence on SME's performance in Indonesia, namely:
Tabel 1.1 Impact of Coronavirus

\begin{tabular}{|c|l|c|}
\hline No & \multicolumn{1}{|c|}{ Effects of the Coronavirus } & Percentage \\
\hline 1 & Reduction the number of officers & $33,23 \%$ \\
\hline 2 & Decreased income & $84,20 \%$ \\
\hline 3 & Financial constraints & $62,21 \%$ \\
\hline
\end{tabular}

Source: www.bps.go.id

(The author has processed the data)

According to Lin et al. (2012), based on its application, it can be classified into 2 (two) groups: the models used for retail products such as personal loans, credit cards, mortgages, and others. For other models, it is commonly referred to as the corporate model. In retail segmentation, the method used is credit scoring, it contains many empirical predictive models that take into account the relationship between default and various debtor characters.

The small business and corporate sectors certainly have different levels of risk. According to Berger and Frame (2007), nearly half of US private sector employment and non-farm domestic products belong to small businesses. Driven by whatever reasons are considered by debtors in applying for restructuring during the coronavirus pandemic, especially for the Small Medium Enterprise (SME), we assume that there is a link between credit scoring as an initial screening or the initial stage of financial institutions providing loans. Funds to customers: In the credit scoring instrument, there are several indicators of assessing the ability of customers to return funds borrowed through their 
business activities or cash flow of customers not from the results of the execution of collateral.

In many countries, The highest proportion of jobs and the majority of businesses are small and medium enterprises (SMEs), according to Abor and Biekpe (2007). With SMEs' economic and social contribution, it is hoped that companies in this segment will grow (Fischer and Reuber 2000).

The purpose of using credit scoring by financial institutions is to improve performance and efficiency in financing. Scoring, especially in statistical scoring according to (Dellien, 2005; Berger, 2007) several advantages can be obtained to improve micro-lending performance, several advantages obtained in applying credit scoring, namely: reducing financing for problematic debtors; improve consistency in decision making; assess risk clearly; improve efficiency in the lending process; the existence of opportunities in the development of new products or product differentiation; implementation of risk-based pricing.

Based on previous research that credit scoring can be applied to various problems in the credit portfolio. From the various credit scoring studies that exist, namely the research on lending policies, value at risk and credit scoring conducted by Tor Jacobson and Kasper Roszbach (2003), they used the bivariate probit model with the result that banks provide loans in a way that is inconsistent with minimizing the risk of default. Banks that are risk-averse in lending still make tradeoffs between credit risk and bank returns. Based on a Basel 2 Environment, Edward I Altman (2002) used for his research to examined Credit scoring models, Capital market risk equivalents, and Probability of Default and Loss Given Default on credit portfolios. This research shows that having models such as Z-Score and Expected Default Frequency is not sufficient in predicting the default. In good or complex conditions, a "credit culture" is needed in financial institutions. It is aimed at evaluating credit risk.

Kasper Roszbach (2004) used the Bivariate Tobit Model method by using a model as a signal in making decisions to provide loans or not and predicting the loan period on Bank Lending Policy. Ahmet Burak Emela, Muhittin Oral, Arnold Reisman and Reha Yolalan (2003), in the commercial banking sector they examined the credit scoring approach. This study uses financial statement performance indicators in the credit scoring methodology used. The results obtained in this study are to provide clear insight into how "bad" companies can improve their financial efficiency. In particular, "good" companies have higher liquidity, relatively small bank loan funds, higher capital adequacy and a better balance between equity and fixed assets. Allen N. Berger and W. Scott Frame (2007) examined commercial banks in the United States that use a credit scoring model to provide small business credit or Small Business Credit
Scoring (SBCS). The use of this model aims to accept or reject credit applications submitted by prospective debtors automatically. The main motive in using this model is to reduce costs in providing credit by the Bank.

Departing from a credit scoring formula that can predict customer credit quality, this study was conducted to provide empirical evidence that several factors can influence the quality of debtor credit facilities during the COVID-19 pandemic. This study is expected to assist regulators, banks and other financial institutions in determining policies for their existing debtors during the pandemic.

\section{LITERATURE REVIEW}

\subsection{Bank Credit}

The banking world is one of the financial institutions that have great risk. The risks faced are sourced from internal or management and from other parties outside the Bank whose activities are directly or indirectly related.

According to Bae and Goyal (2009) that in each country has a different pattern of policies in terms of lending, borrowers with relatively higher quality will certainly qualify for loans from banks. There are differences in each country in the focus of the type of industry or sector that is the lending target. This shows that banks respond to different legal risks in various ways.

In Andrianto (2020), credit has several elements contained in it, namely:

1. Time, is a time gap between the approval of the credit and its repayment.

2. Trust, namely the provision of credit, is based on the creditor's trust to the debtor on an agreement that both parties have approved.

3. Delivery, namely a statement from the creditor that it will distribute economic value to the debtor and must be returned by the debtor according to the agreed period.

4. Risk, namely the risk that may arise during the period between granting the debt until it is paid off.

5. Approval and agreement, i.e., a contract between lender and debtor of funds, can be proven by the existence of a deal.

\subsection{Credit Scoring}

According to Kočenda and Vojtek (2009), in the lender's asset portfolio, lending in the retail segment is one of the most profitable investments in the lender's asset portfolio. An increase in the number of loans also 
has the effect of increasing the number of defaulted loans. So, every lender's main problem is distinguishing between "low risk" and "high risk" before extending credit. Due to the information asymmetry between lenders and borrowers, such distinction is not an easy task. For this reason, a method of providing loans to borrowers is needed. In the banking world, it is known as credit scoring.

According to Berger (2007), credit scoring can be used as a tool by the lender to predict the probability of default. This is in line with what is explained in The World Bank Group (2019) that credit scoring can predict the borrower's (debtor) ability to pay, or expect the probability of default on borrowed funds. So the use of credit scoring provides convenience in terms of estimating the possibility of bankruptcy or default

In the 1960s, the credit scoring method was first applied, its application at that time was when the decision to give credit cards automatically, which was later developed in other business segments, namely small and medium enterprises (SME). Myers and Forgy (1963) compared the discriminant analysis with regression in the Credit Scoring application. Beaver introduced the bankruptcy prediction model in 1966. The two studies above have similarities that focus on two aspects: failure prediction and credit quality classification. These aspects are quite important in empirical analysis. Altman (1980) described the bank loan process as an integrated system for analyzing how loan assessments are determined.

In increasing economic growth, in terms of loans, facilities, and equitable distribution are needed in various business fields, healthy loan quality is also an essential factor in economic growth. A method is required to predict loans and to maintain the quality of the loan. For the past few years, the credit scoring method has been considered capable of helping economic improvement by predicting the quality of loans disbursed.

There is a change in credit decision making, which initially used the traditional method to the credit scoring method, whether to accept or reject credit applications. The methods used for credit scoring have improved in recent years.

Departing from the summary of the literature and previous research described above, we have a hypothesis that business's age, loan limit, income (income or turnover), business type (legal entity or not) and Net Profit Margin have a relationship with debtor submissions in restructuring their credit facilities due to affected by the coronavirus pandemic.

There is a discriminant analysis method that is included in the credit scoring category, which Ronald A. Fisher first introduced (Fisher, 1936). Credit scoring indicates the feasibility of granting credit. The World
Bank Group (2019) states that usually, a numerical expression indicates how likely it is that the consumer or business will make regular and full credit payments.

Based on The World Bank Group (2019) that there are several important things in the development of credit scoring, including:

a. Traditional Credit Scoring Method

1) Linear Regression

This approach is a method that uses a numerical scale in its approach, both for the dependent and independent variables.

\section{2) Discriminant Analysis}

A method of regression analysis used for classification. This method uses categorical data to interpret the variable. The simplest interpretation is a label with two categories. Sir Ronald Fisher developed the original linear dichotomous discriminant analysis in 1936 (Fisher, 1936).

The first method used to make the default prediction is discriminant analysis, which explains which company the debtor predicts will go bankrupt, the model that is still used today by using financial statement variables is Altman's model (Altman, 1968).

The Altman Z-score model (Altman, 1968), is as follows:

$$
\mathrm{Z}=\beta \mathrm{X}_{1}+\beta \mathrm{X}_{2}+\beta \mathrm{X}_{3}+\beta \mathrm{X}_{4}+\beta \mathrm{X}_{5}
$$

Where,

$$
\begin{aligned}
& X_{1}=\text { working capital } / \text { total assets } \\
& X_{2}=\text { retained earnings } / \text { total assets } \\
& X_{3}=\text { profit before interest and taxes } / \text { total assets } \\
& X_{4}=\text { market value of equity } / \text { book value of total } \\
& \text { liabilities } \\
& X_{5}=\text { sales / total assets }
\end{aligned}
$$

\section{3) Probit Analysis and Logistik Regression}

The probability value can be seen not only by using a numerical or continuous scale. There are several methods that can predict the probability value. In the probit model, the abbreviation for "probability" is modeled as a linear combination. The logit function uses the $\log$ of odds. Analogously to probit, in the logit model, the $\log$ odds ratio label is modeled as a linear combination.

This model also known as a model for estimating the default probability, this model is easy to develop and easily validates, calibrates and interprets data. In contrast to other models with benchmarks that minimize squared errors, estimates in logistic regression choose 
the parameter that maximizes the probability of observing the sample value.

\section{4) Judgment Based Models}

Judgment Based Decision Model has several methods in its application, one of which is the Analytic Hierarchy Process, this method has the function to organize and analyze complex matters. The Analytic Hierarchy Process (AHP) model has principles such as when a decision is needed on a problem, judgment is taken based on the information and other factors, representing hierarchical information. The key to AHP is a human judgment by assigning a subjective value to the importance of each variable.

\section{a. Credit Scoring Risk}

1) Fairness

According to World Bank and CGAP (2018), Algorithms are used in processing data sources by detecting personal data and ethical boundaries, such as race, gender, or religion. Thus, upholding human rights and ethics is the method applied in credit scoring.

\section{2) Interpretability}

Using algorithms that are too complex can affect the result of transparency. The ambiguity of the algorithm can be a cause for concern. When the algorithm is used to assign a credit score to credit decisions, an explanation of the credit result decisions is generally more difficult.

With a lack of interpretation, algorithms can affect macro risk, this will certainly happen if the regulator does not provide an offer. With many models that can be used will make the model more difficult to explain or interpret. The lack of interpretation will lead to a potential cascading effect due to the interconnectedness of the system. The algorithm was developed in a period of low volatility so that in the event of a significant economic downturn or financial crisis, this model cannot be used.

\section{3) Accountability}

With algorithms in financial institutions, it is possible that the process is not familiar with what legal institutions and regulators understand. The financial institution is using the algorithm depending on third parties. It is feared that financial institutions cannot monitor third parties because they are not parties supervised by the regulator.

The potential development of technology can lead to increased dependence on third parties. With the increasing number of Information Technology (IT)based companies offering various algorithm innovations that can be used in determining credit distribution.

\section{4) Data Privacy}

According to World Bank and CGAP (2018), there are increasing public concerns about customer data privacy and transparency about how that data is collected, processed, and used from online data trails and other information.

The digital credit decision process can be carried out in a non-transparent manner, using specific unpublished methods. The credit decision process can be carried out by not providing details on how customer data is collected. Based on The World Bank Group (2019), most developing countries have limitations regarding applicable laws to regulate the use of personal data for credit process.

\section{5) Data Security}

Credit scoring requires a Credit Scoring Provider (CSP) to store and access huge consumer and business personal data volumes. Thus, it is necessary to increase security along with the increasing risk of identity theft.

\section{METHODS}

This research was conducted using data on debtors who had never applied for restructuring at Bank XYZ until the end of 2019. During the coronavirus pandemic, they proposed restructuring their credit facilities at Bank $\mathrm{XYZ}$ because the debtor's business application was affected by coronavirus.

The population and samples obtained were from existing debtors at Bank XYZ located in Jakarta, Bogor, Depok, Tangerang and Bekasi. The criteria used for sampling in this study are:

a) Debtors who have Working Capital Credit facilities.

b) The debtor has a relationship with Bank XYZ for at least 5 (five) years before the research is conducted.

c) Before the COVID-19 pandemic, the debtor had never restructured credit facilities at Bank XYZ

The dependent variable data used is December 2019 position data, debtor profile data, including information on the length of business of the debtor, debtor limits at Bank XYZ, revenue on sales and Net Profit Margin. In March until April 2020 data on debtor groups who applied for COVID19 credit restructuring and those who did not apply for COVID19 restructuring. We used 500 samples in this research, with 250 debtors who applied for debt restructuring and 250 debtors who did not apply for debt restructuring.

The criteria of debtor profile are the debtor must have working capital credit facility at XYZ Bank, has a credit relationship with XYZ Bank for at least 5 (five) 
years and before the COVID-19 pandemic, the debtor had never restructure their debt at XYZ Bank.

This study uses secondary data, data from the SME (Small Medium Enterprise) division in the form of personal data of Bank XYZ customers who have Working Capital facilities. The data consists of 500 customers with 5 (five) variables.

\subsection{Definition of Research Variables}

a. Dependent Variable:

The dependent variable used in this study is the debtor who proposed the restructuring of COVID-19 in this study, it was written with the following conditions:

Value 1: Debtors who apply for debt restructuring COVID-19

Value 0 : Debtors who do not apply for COVID-19 restructuring

b. Variable Independent

1) Business's Age

In this variable, the age or duration of the business running, there are two categories, namely Business Entities and Individuals, with the following provisions:

- Business entity (Company)

The business age of a business entity can be seen from the deed of establishment of the company.

- Individual

The age of the current business for individuals is seen from the date of the Taxpayer Identification Number or Trade Business License.

2) Limit

The limit used in this study is the limit of the debtor's credit facility at Bank XYZ

3) Income

Sales before the coronavirus pandemic. In this study, we used the financial statement period of 2019.

4) Legal Form of Business

Value 1 : Company

Value 0 : Individual

5) Net Profit Margin (NPM)

The NPM value used is the NPM in the 2019 financial reporting period or before the coronavirus pandemic.

The description of the variables that we used in this study:
Tabel 3.1 Description of The Variables

\begin{tabular}{|c|c|c|c|}
\hline Variable & Definition & Measurement & $\begin{array}{l}\text { Data source } \\
\end{array}$ \\
\hline $\begin{array}{l}\text { Dependen: } \\
\text { COVID-19 Debt } \\
\text { Restructuring }\end{array}$ & $\begin{array}{l}\text { Is a restructuring } \\
\text { of credit facilities } \\
\text { due to the impact } \\
\text { of COVID-19 }\end{array}$ & $\begin{array}{l}\text { Applying for a COVID-19 Debt } \\
\text { Restructuring }\end{array}$ & $\begin{array}{l}\text { XYZ Bank credit } \\
\text { decision }\end{array}$ \\
\hline $\begin{array}{l}\text { Independen : } \\
\text { Business's Age }\end{array}$ & $\begin{array}{l}\text { Is the age the } \\
\text { business }\end{array}$ & $\begin{array}{l}\text { - Business entity (Company) } \\
\text { The business age of a business } \\
\text { entity can be seen from the } \\
\text { deed of establishment of the } \\
\text { company. } \\
\text { - Individual } \\
\text { The age of the current business } \\
\text { for individuals is seen from the } \\
\text { date of the NPWP (Taxpayer } \\
\text { Identification Number) or } \\
\text { SIUP (Trade Business } \\
\text { License). }\end{array}$ & $\begin{array}{l}\text { Debtor's business } \\
\text { legality }\end{array}$ \\
\hline $\begin{array}{l}\text { Independen : } \\
\text { Limit }\end{array}$ & $\begin{array}{l}\text { Is the limit on the } \\
\text { facilities owned at } \\
\text { Bank XYZ }\end{array}$ & Limit at Bank XYZ & $\begin{array}{l}\text { Summary Bank } \\
\text { Checking }\end{array}$ \\
\hline $\begin{array}{l}\text { Independen: } \\
\text { Income }\end{array}$ & $\begin{array}{l}\text { Represents } \\
\text { debtor's income or } \\
\text { sales }\end{array}$ & $\begin{array}{l}\text { Debtor's income in } 1 \text { (one) year } \\
\text { in the period } 2019 \text { (before } \\
\text { COVID-19) }\end{array}$ & $\begin{array}{l}\text { Financial } \\
\text { statements }\end{array}$ \\
\hline $\begin{array}{l}\text { Independen: } \\
\text { Type of Busniness }\end{array}$ & \begin{tabular}{ll|} 
Company & or \\
Individual &
\end{tabular} & $\begin{array}{l}\text { - Value } 1 \text { : Company } \\
\text { - Value } 0 \text { : Individual }\end{array}$ & $\begin{array}{l}\text { Summary Bank } \\
\text { Checking }\end{array}$ \\
\hline $\begin{array}{l}\text { Independen: } \\
\text { Net Profit Margin } \\
\text { (NPM) }\end{array}$ & $\begin{array}{l}\text { Is the margin } \\
\text { between net profit } \\
\text { and income }\end{array}$ & $\begin{array}{l}\text { NPM debtor in the } 2019 \text { reporting } \\
\text { period (before COVID-19) }\end{array}$ & $\begin{array}{l}\text { Financial } \\
\text { statements }\end{array}$ \\
\hline
\end{tabular}

\subsection{Data Analysis}

In this research, we use quantitative analysis techniques. Quantitative analysis is a technique that analyzes data that can be explained quantitatively to produce the information needed to analyze the data.

The analytical methods that we used in this study are:

- The logistic regression method, and

- The discriminant analysis.

The selection of this method is based on non-metric data on the dependent variable and a mixture of continuous (metric data) and categorical (non metric data) variables. With a combination of scales on the independent variables, the multivariate normal distribution is not fulfilled. Thus, there is no need to change the function to logistic and use the assumption of normality on the independent variables.

\section{a. Binary Logistic Regression Method}

According to Santoso (2018), the analysis used to analyze quantitative data and reflect two choices are called binary logistic regression. The variable that uses this method is the type of business (business entity or 
individual). The analysis of this research was carried out using the SPSS 26 program.

With categorical data, of course, it has the same variance, therefore logistic regression does not need to be tested for heteroscedasticity. This is because the data is already homogeneous, so the logistic regression analysis stage will only consist of descriptive statistical analysis and hypothesis testing. The following tests are used in this method:

\section{1) Descriptive Statistics}

Descriptive statistics function as a tool to describe the data used in research. Descriptive statistics is a process of transforming data presented in tabulated form in the form of a summary of compilation in the form of tables and graphs so that it can then be easily understood and interpreted. In general, to provide information on the characteristics of research variables, we use descriptive statistics.

Descriptive statistics provide an overview of data that can be seen based on the average value (mean), standard deviation, variance, and minimum-maximum (Santoso, 2018).

\section{2) Research Hypothesis Testing}

In general, research can use a significance level of $1 \%, 5 \%$, or $10 \%$ (Santoso, 2018). This study was conducted using a significance level of $0.05(\alpha=5 \%)$.

\section{3) Wald test}

In logistic regression, the use of the Wald test aims to test whether there is an effect of the independent variable on the dependent variable partially, namely by comparing the Wald value with the comparison value of Chi-square at degrees of freedom $(\mathrm{db})=1$ for alpha $5 \%$, or by comparing the significance value ( $p$-value) for an alpha of $5 \%$ where the p-value is smaller than alpha which indicates that the hypothesis is not rejected or there is a significant effect of the independent variable on the dependent variable partially (Widarjono, 2010: 123).

\section{4) Coefficient of Determination (Nagelkerke R Square)}

Cox and Snell's R Square is a measurement method that tries to imitate the $\mathrm{R}$ measurement method in multiple regression based on the likelihood estimation technique with a maximum value of less than 1 so it is difficult to interpret. To obtain a coefficient of determination, it can be interpreted as the value of $\mathrm{R} 2$ in the multiple regression method, this study uses the Nagelkerke R Square.

Based on the above method for this research, the variable used with the Binary Logistic Regression method is the submission of Covid-19 restructuring by the debtor (dependent variable) with the type of debtor's business (independent variable). So that the following equation is obtained:

Credit Restructuring $=\beta 0+\beta 1$ Type of Business $+\varepsilon$

\section{b. Discriminant Analysis Method}

According to Santoso (2018), in principle, a discriminant analysis must go through the following processes:

1) Choosing a discriminant analysis method this analysis has 2 (two) basic methods, namely:

a) Simultaneous Estimation

This method uses all variables together to interpret.

b) Step-Wise Estimation

This method is different from Simultaneous Estimation, namely by entering the variables one by one into the discriminant model. In this process, fixed variables are used as models, and it is possible that the model does not use all of the existing independent variables.

2) We use Wilk's Lambda to Test the significance of the discriminant function, $\mathrm{F}$ Test, and others.

3) Test the classification accuracy of the discriminant function with Casewise Diagnostics.

4) Interpreting the discriminant function.

5) Perform validation test on the discriminant function.

Based on the above method for this research, the variables used are discriminant analysis methods for the submission of Covid-19 restructuring by debtors (dependent variable) and the independent variables are business age (Age), Limit, Income (income) and Net profit margin (NPM). So that the following equation is obtained:

\section{$\mathrm{CR}^{*}=\beta 0+\beta$ Business's Age $+\beta$ Limit $+\beta$ Income + $\beta \mathrm{NPM}+\varepsilon$ \\ $* \mathrm{CR}=$ Credit Restructuring}

\section{RESULTS}

\subsection{Logistics Binary Regression Method}

Based on the descriptive statistical test results, 500 observations were obtained from 250 debtors who proposed COVID-19 restructuring and 250 debtors who did not apply for COVID-19 restructuring. The independent variable being tested for this method is the Legal Form of Business (Legal Entity or Individual).

Tabel 4.1 Descriptive

Descriptive Statistics

\begin{tabular}{|l|r|r|r|r|r|}
\hline & \multicolumn{1}{|c|}{$\mathrm{N}$} & Minimum & Maximum & \multicolumn{1}{c|}{ Mean } & Std. Deviation \\
\hline Legal Form of Business & 500 & .00 & 1.00 & .6740 & .46922 \\
Valid N (listwise) & 500 & & & & \\
\hline
\end{tabular}


Based on the table above, the type of business shows a minimum value of 0 , a maximum value of 1 with an average of 0.6740 , and a standard deviation of 0.46922 . The average value of 0.6740 indicates that the research sample has 337 forms of business law in the form of legal entities and 163 types of businesses in the form of individuals.

\section{Tabel 4.2 Wald's Test}

\begin{tabular}{|c|c|c|c|c|c|c|c|}
\hline \multicolumn{8}{|c|}{ Variables in the Equation } \\
\hline & & $\overline{\mathrm{B}}$ & S.E. & Wald & $d f$ & Sig. & $\operatorname{Exp}(B)$ \\
\hline Step $1^{a}$ & Company_Individual & .797 & .196 & 16,523 & 1 & .000 & 451 \\
\hline & Constant & 540 & .162 & 11.072 & 1 & .001 & 1.717 \\
\hline
\end{tabular}

a. Variable(s) enteresd on step 1: Company_Individual.

Based on the table, the Type of Business variable obtained a wald value of 16.523 (sig. 0.000). The odd ratio value of 0.451 indicates that legal forms of business that are legal entities (company or corporate) tend to apply for credit restructuring 0.451 times higher than legal forms of individual businesses. It can be concluded that the accepted hypothesis is that the debtor's Business Legal Form variable influences the debtor's submission for COVID-19 credit restructuring.

Tabel 4.3 Coefficient of Determination

\begin{tabular}{|c|c|c|c|}
\hline \multicolumn{4}{|c|}{ Model Summary } \\
\hline Step & -2 Log likelihood & $\begin{array}{c}\text { Cox \& Snell R } \\
\text { Square }\end{array}$ & $\begin{array}{c}\text { Nagelkerke R } \\
\text { Square }\end{array}$ \\
\hline 1 & $676.167^{9}$ & .033 & .045 \\
\hline
\end{tabular}

a. Estimation terminated at iteration number 3 because parameter estimates changed by less than .001 .

The value of Nagelkerke $\mathrm{R}$ Square indicates the value of the coefficient of determination used in this study. The Nagelkerke R Square value obtained is 0.045 , which means the dependent variable that the independent variable can explain is $4.5 \%$.

\subsection{Discriminant Analysis Method}

In this study, we use the Step-Wise Estimation method as the discriminant model, as previously explained that this method is used by entering the variables one by one into the discriminant model. The following are some of the methods applied in this research:

\section{a. Analysis of Case Processing Summary}

The following SPSS results show that the processed data shows $100 \%$ validation, and there is no missing data from the grouping. This study indicates that all 500 samples have their respective groups.
Tabel 4.4 Case Processing Summary

\begin{tabular}{|c|c|c|c|}
\hline \multicolumn{2}{|c|}{ Unweighted Cases } & $\mathrm{N}$ & Percent \\
\hline \multicolumn{2}{|l|}{ Valid } & 500 & 100.0 \\
\hline \multirow[t]{5}{*}{ Excluded } & Missing or out-of-range group codes & 0 & .0 \\
\hline & $\begin{array}{l}\text { At least one missing discriminating } \\
\text { variable }\end{array}$ & 0 & .0 \\
\hline & Both missing or out-of-range group & & \\
\hline & $\begin{array}{l}\text { codes and at least one missing } \\
\text { discriminating variable }\end{array}$ & 0 & .0 \\
\hline & Total & 0 & .0 \\
\hline Total & & 500 & 100.0 \\
\hline
\end{tabular}

\section{b. Multicollinearity Test}

To fulfill discriminant analysis, a multicollinearity test is needed:

Tabel 4.5 Multicollinearity Test

Pooled Within-Groups Matrices

\begin{tabular}{|ll|r|r|r|r|}
\hline & \multicolumn{1}{|c|}{$\begin{array}{c}\text { Business's } \\
\text { Age }\end{array}$} & \multicolumn{1}{c|}{ Limit } & Income & \multicolumn{1}{c|}{$\begin{array}{c}\text { Net Profit } \\
\text { Margin }\end{array}$} \\
\hline Correlation & Business's Age & 1.000 & -.109 & -.055 & .024 \\
& Limit & -.109 & 1.000 & .527 & .038 \\
& Income & -.055 & .527 & 1.000 & -.041 \\
& Net Profit Margin & .024 & .038 & -.041 & 1.000 \\
\hline
\end{tabular}

From the results, the variable has no correlation, for the limit and income values, it has a value of 0.527 (rounded up to 0.5), so it can be concluded that the variables used for discriminant analysis in this study are not correlated between variables.

\section{c. Tests of Wilk's Lambda}

Based on the results of research data processing that the cause of the COVID-19 restructuring proposal by the debtor can be seen through the value of Wilk's Lambda with the following significance:

\section{Tabel 4.6 Wilk’s Lambda}

\begin{tabular}{|l|r|r|r|r|r|}
\multicolumn{7}{|c|}{ Tests of Equality of Group Means } \\
\hline & \multicolumn{1}{|c|}{$\begin{array}{c}\text { Wilks' } \\
\text { Lambda }\end{array}$} & \multicolumn{1}{c|}{ F } & \multicolumn{1}{c|}{ df1 } & \multicolumn{1}{c|}{ df2 } & \multicolumn{1}{c|}{ Sig. } \\
\hline Business's Age & .976 & 12.169 & 1 & 498 & .001 \\
Limit & .775 & 144.404 & 1 & 498 & .000 \\
Income & .705 & 208.243 & 1 & 498 & .000 \\
Net Profit Margin & .998 & .812 & 1 & 498 & .368 \\
\hline
\end{tabular}

From the table above, it can be concluded that the differentiating variables for the COVID-19 restructuring proposal can be influenced by the business age, limit and income of the debtor.

\section{d. Discriminant Function}

In this study, in determining the discriminant function: 
Tabel 4.7

Canonical Discriminant

Function Coefficients

\begin{tabular}{|l|r|}
\hline & Function \\
\cline { 2 - 2 } & \multicolumn{1}{|c|}{1} \\
\hline Business's Age & .055 \\
Limit & .000 \\
Income & .001 \\
(Constant) & -2.365 \\
\hline
\end{tabular}

Unstandardized coefficients

The discriminant function is obtained as follows;

SCORE $=-2.365+0,055$ Business's Age $+0,000$

Limit + 0,001 Income

\section{e. Prediction Model}

The midpoint of each discriminant value between the 2 (two) groups:

Tabel 4.8 Functions at Group Centroids

Functions at Group Centroids

\begin{tabular}{|l|r|}
\hline \multicolumn{2}{|c|}{ Functions at Group Centroids } \\
\cline { 2 - 2 } Apply for Debt Restructuring & \multicolumn{1}{|c|}{ Function } \\
\hline Not Apply for Debt Restructuring & .719 \\
Apply for Debt Restructuring & -.719 \\
\hline
\end{tabular}

Unstandardized canonical discriminant functions

evaluated at group means

The discriminant value close to 0.719 are debtors who have a tendency not to apply for COVID-19 restructuring, while debtors with discriminant values close to 0.719 are debtors who propose COVID-19 restructuring. Determine the limit value in this study (discriminant value cut off) can be calculated by the following formula:

$$
\mathrm{CO}=\mathrm{n} 1 \mathrm{GC} 1+\mathrm{n} 2 \mathrm{GC} 2 /(\mathrm{n} 1+\mathrm{n} 2)
$$

It is known that $\mathrm{CO}$ is the Cut Off Point, which separates the two groups, GC is the Group Centroid. With the values of $\mathrm{n} 1$ and $\mathrm{n} 2$ each being 250 , the calculation of the GC on the Cut Off is as follows:

$$
\begin{aligned}
\mathrm{CO} & =250 \times 0,719+250 \times-0,719 / 500 \\
& =0
\end{aligned}
$$

So for the values of $\mathrm{GC}$ and $\mathrm{CO}$ can be described as follows:

$$
\begin{aligned}
& \text { Apply for Debt Restructuring Not Apply for Debt Restructuring }
\end{aligned}
$$

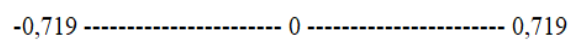

Based on the previous discriminant function and prediction model, we can manually predict whether the debtor will apply for COVID-19 credit restructuring or not, for example: Debtors with a business age of 12 years, with a limit of Rp. 2,200 (million) and income of Rp. 1.100 million/month (Rp.1.1 billion/month). Whether the debtor tends to apply for restructuring or not can be seen from the following calculation:

$$
\begin{aligned}
\text { SCORE }= & -2.365+0,055 \text { Business's Age }+0,000 \\
& \text { Limit }+0,001 \text { Income } \\
\text { SCORE }= & -2.365+\left(0,055^{*} 12\right)+(0,000 * 2.200)+ \\
& (0,001 * 1.100)=-0.605
\end{aligned}
$$

The value -0.605 is the value to the left of $\mathrm{CO}(0)$, meaning that the debtor is in the group of debtors who are applying for COVID-19 restructuring.

\section{CONCLUSIONS}

This study aims to examine the profile of the debtor, namely the length of the debtor's business age (Age), the debtor's loan limit, the debtor's income (income), the line of business (Company or Individual), and the debtor's profitability (Net Profit Margin) against the decision to apply for COVID-19 restructuring at the Bank XYZ.

Based on the results of statistical tests that have been carried out, it can be concluded that the debtor's decision to apply for COVID-19 restructuring can be concluded as:

1. Business age can explain the difference between debtors who apply for debt restructuring, and those who did not, where the longer the business age, the higher the probability of debtors applying for debt restructuring

2. Debtor's loan limits can explain the difference between debtors who apply for debt restructuring, and those who did not apply for restructuring, where the larger the debtor's loan limit, the higher the probability of the debtor applying for credit restructuring.

3. Debtor's income can explain the difference between debtors who apply for debt restructuring, and those who did not apply for restructuring, where the higher the debtor's income, the higher the probability of the debtor applying for credit restructuring.

4. There is an influence of the type of business (individual or company) of the debtor on the debtor's decision to apply for COVID-19 restructuring.

5. There is an effect of differences in the form of business type (company or individual) on the debtor's decision to apply for credit restructuring, where debtors with a corporate form of business have 0.451 times the opportunity to apply for credit restructuring compared to debtors with individual business types

6. There is no influence of net profit margin on the debtor's decision to apply for COVID-19 restructuring. 


\section{REFERENCES}

[1] Altman, E. I. (1968). Financial Ratios, Discriminant Analysis And The Prediction of Corporate Bankruptcy. The Journal of Finance, 23(4), 589609. doi:10.1111/j.1540-6261.1968.tb00843.x

[2] Altman, E., I. (1980). Commercial Bank Lending: Process, Credit Scoring, and Costs of Errors in Lending. The Journal of Financial and Quantitative Analysis, 15(4), 813. doi:10.2307/2330559

[3] Altman, E., I. (2002). Revisiting Credit Scoring Models in a Basel 2 Environment. NYU Working Paper No. FIN-02-041

[4] Andrianto, SE, M.Ak. (2020). Manajemen Kredit: Teori dan Konsep Bagi Bank Umum. Pasuruan, Jawa Timur: CV. Penerbit Qiara Media.

[5] Bae, K.-H., \& Goyal, V. K. (2009). Creditor Rights, Enforcement, and Bank Loans. The Journal of Finance, 64(2), 823-860. doi:10.1111/j.15406261.2009.01450.x

[6] Bank Indonesia, Peraturan Bank Indonesia Nomor 5/8/PBI/2003 tentang Penerapan Manajemen Risiko bagi Bank Umum, Lembaran Negara Republik Indonesia Tahun 2003 Nomor 56, Tambahan Lembaran Negara Nomor 4292.

[7] Bank Indonesia, Surat Edaran Bank Indonesia No.13/24/DPNP/2011 tanggal 25 Oktober 2011 tentang Penilaian Tingkat Kesehatan Bank Umum. Jakarta.

[8] Bank Indonesia. Peratruran Bank Indonesia (PBI) No. 14/15/PBI/2012. Oktober 2012. https://peraturan.bpk.go.id/Home/Details/137449/p eraturan-bi-no-1415pbi2012

[9] Basel Committee on Banking Supervision; International Convergence of Capital Measurement and Capital Standards: A Revised Framework, June 2004, rev. June 2006 (Basel II).

[10] Beaver, W., H. (1966). Financial Ratios As Predictors of Failure. Journal of Accounting Research, 4, 71. doi:10.2307/2490171

[11] Berger, A. N., \& Frame, W. S. (2007). Small Business Credit Scoring and Credit Availability. Journal of Small Business Management, 45(1), 522. doi:10.1111/j.1540-627x.2007.00195.x

[12] Berger, A., Frame, W, S., \& Miller, N. H. (2005). Credit Scoring and the Availability, Price, and Risk of Small Business Credit. Journal of Money, Credit and Banking, Vol. 37, No. 2 (Apr., 2005), pp. 191-222. doi:10.1353/mcb.2005.0019
[13] Berger, A., Marisa B., Livingston P. \& Klein, N. (2007). Credit Scoring for Microenterprise Lenders. Microenterprise Fund for Innovation, Effectiveness, Learning and Dissemination. Washington DC: The Aspen Institute.

[14] Chakraborty, I., \& Maity, P. (2020). COVID-19 outbreak: Migration, effects on society, global environment and prevention. Science of The Total Environment, 138882. doi:10.1016/j.scitotenv.2020.138882

[15] Dellien, H., \& Schreiner, M. (2005). Credit Scoring, Banks, and Microfinance: Balancing High Tech with High Touch. Microenterprise Development Review, Vol. 8, No. 2, pp. 1-5.

[16] Emel, A. B., Oral, M., Reisman, A., \& Yolalan, R. (2003). A credit scoring approach for the commercial banking sector. Socio-Economic Planning Sciences, 37(2), 103123. doi:10.1016/s0038-0121(02)00044-7

[17] Fisher, R., A. (1936). "The Use of Multiple Measurements in Taxonomic Problems." Annals of Eugenics 7 (2): 179-88. doi:10.1111/j.14691809.1936.tb02137.x

[18] Huang, C., Wang, Y., Li, X., Ren, L., Zhao, J., Hu, Y., ... Cao, B. (2020). Clinical features of patients infected with 2019 novel coronavirus in Wuhan, China. The Lancet. doi:10.1016/s01406736(20)30183-5

[19] Jacobson, T., \& Roszbach, K. (2003). Bank lending policy, credit scoring and value-at-risk. Journal of Banking \& Finance, 27(4), 615-633. doi:10.1016/s0378-4266(01)00254-0

[20] Kemetrian Keungan No. 2. Maret 2020. https://www.sdm.kemenkeu.go.id/peraturan/doc/S E-

2.MK.1.2020\%20Pencegahan\%20Penyebaran $\% 20$ COVID-19.pdf

[21] Kočenda, E., \& Vojtek, M. (2009). Default predictors and credit scoring models for retail banking. CESifo Working Paper Series No. 2862

[22] Myers, J. H., \& Forgy, E. W. (1963). The Development of Numerical Credit Evaluation Systems. Journal of the American Statistical Association, $58 \quad$ (303), 806. doi:10.1080/01621459.1963.10500889

[23] Otoritas Jasa Keuangan. Peraturan Otoritas Jasa Keuangan (POJK) No. 40/POJK.03/2019. Desember 2019. https://www.ojk.go.id/id/regulasi/Pages/PenilaianKualitas-Aset-Bank-Umum.aspx 
[24] Roszbach, K. (2004). Bank Lending Policy, Credit Scoring, and the Survival of Loans. Review of Economics and Statistics, 86(4), 946958. doi:10.1162/0034653043125248

[25] Santoso, Singgih. (2018). Mahir Statistik Multivariat dengan SPSS. Jakarta: PT. Elex Media Komputindo.

[26] Yoo, J.H., (2020). The fight against the 2019-nCoV outbreak: an arduous march has just begun. J.
Korean
Med.
Sci.,
$35-56$

https://doi.org/10.3346/jkms.2020.35.56. 